IRA-International Journal of Management \& Social Sciences

ISSN 2455-2267; Vol.05, Issue 03 (2016)

Pg. no. 414-426

Institute of Research Advances

http://research-advances.org/index.php/RAJMSS

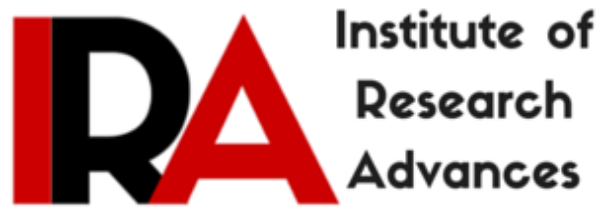

\title{
Greece Crisis: Critical Analysis of Failure of Governance
}

\section{Dr. Sandeep Nath Modi}

Assistant Professor, National Institute of Financial Management, Ministry of Finance, Government of India, India.

Type of Review: Peer Reviewed.

DOI: http://dx.doi.org/10.21013/jmss.v5.n3.p4

How to cite this paper:

Modi, S. (2016). Greece Crisis: Critical Analysis of Failure of Governance. IRAInternational Journal of Management \& Social Sciences (ISSN 2455-2267), 5(3), 414426. doi:http://dx.doi.org/10.21013/jmss.v5.n3.p4

(C) Institute of Research Advances

(cc) EY-NC

This work is licensed under a Creative Commons Attribution-Non Commercial 4.0 International License subject to proper citation to the publication source of the work.

Disclaimer: The scholarly papers as reviewed and published by the Institute of Research Advances (IRA) are the views and opinions of their respective authors and are not the views or opinions of the IRA. The IRA disclaims of any harm or loss caused due to the published content to any party. 


\begin{abstract}
Greece, which is one of the world's largest shipping powers, is suffering from financial crisis in Euro Zone. It has impaired the European Economy, besides having an impact on World Economy too. Greece is exposed to huge debt crises owing to IMF, Germany, Spain, Italy, other European Members and European Central Bank. Recently, Greece is trying to strike a deal with its creditors for extension of time for repayment of the loan and have also requested to increase the limit of emergency funding by European Central Bank. The Government has also taken many steps on domestic level to stop the liquidity easing from its financial system and markets. Today, Greece is at cross-road between the Government and the Governance. This Paper dwells on four aspects; first, critical analysis of Greece Economic Structure to know the actual economic condition of Greece. Second, in depth examining the debt portfolio of Greece to know the exposure of the Greece to the European Union Members, European Central Bank, IMF, Private Investors and also critical analysis of Greece Debt Structure along with repayment deadlines. Third, Greece Government's decisions regarding finding the solutions to counter the financial crisis as to know how governance is more important than growth. And fourt, what would be the repercussions on Greece if it decides/made to leave Euro Zone.
\end{abstract}

JEL Classification: O40, G01

Keywords: Economic Growth, Euro Zone Crisis, Financial Crisis, Governance, Repayment Deadlines

\title{
1. Introduction
}

Governance can be defined in different ways, and more so when we talk of corporate governance versus governance in general. In the context of economic growth and development, governance refers to essential parts of the broad cluster of institutions. Particularly, important elements of governance as defined, would include the political institutions of a society (the process of collective decision making and the checks on politicians, and on politically and economically powerful interest groups), state capacity (the capability of the state to provide public goods in diverse parts of the country) and regulation of economic institutions (how the state intervenes in encouraging or discouraging economic activity by various actors). Thus, the interactions between governance and growth are intimately linked to the interactions between institutions (broadly construed) and economic growth. We might even say good governance is development itself. So, good governance is both an end and a means. It is a key goal of development, broadly construed, and it is also an instrument for achieving better policymaking and improved economic outcomes.

Greece is a democratic and developed country with an advanced high-income economy, a high quality of life and a very high standard of living. A founding member of the United Nations, Greece joined European Communities on $01^{\text {st }}$ January 1981 and adopted Euro in 2001. Greece represents only 2 per cent of the Euro Zone GDP. It is also a member of numerous other International Institutions, including the Council of Europe, NATO (North Atlantic Treaty Organization), OECD (The Organization for Economic Co-operation and Development), OSCE (Organisation for Security and Co-operation in Europe) and the WTO (World Trade Organization). 


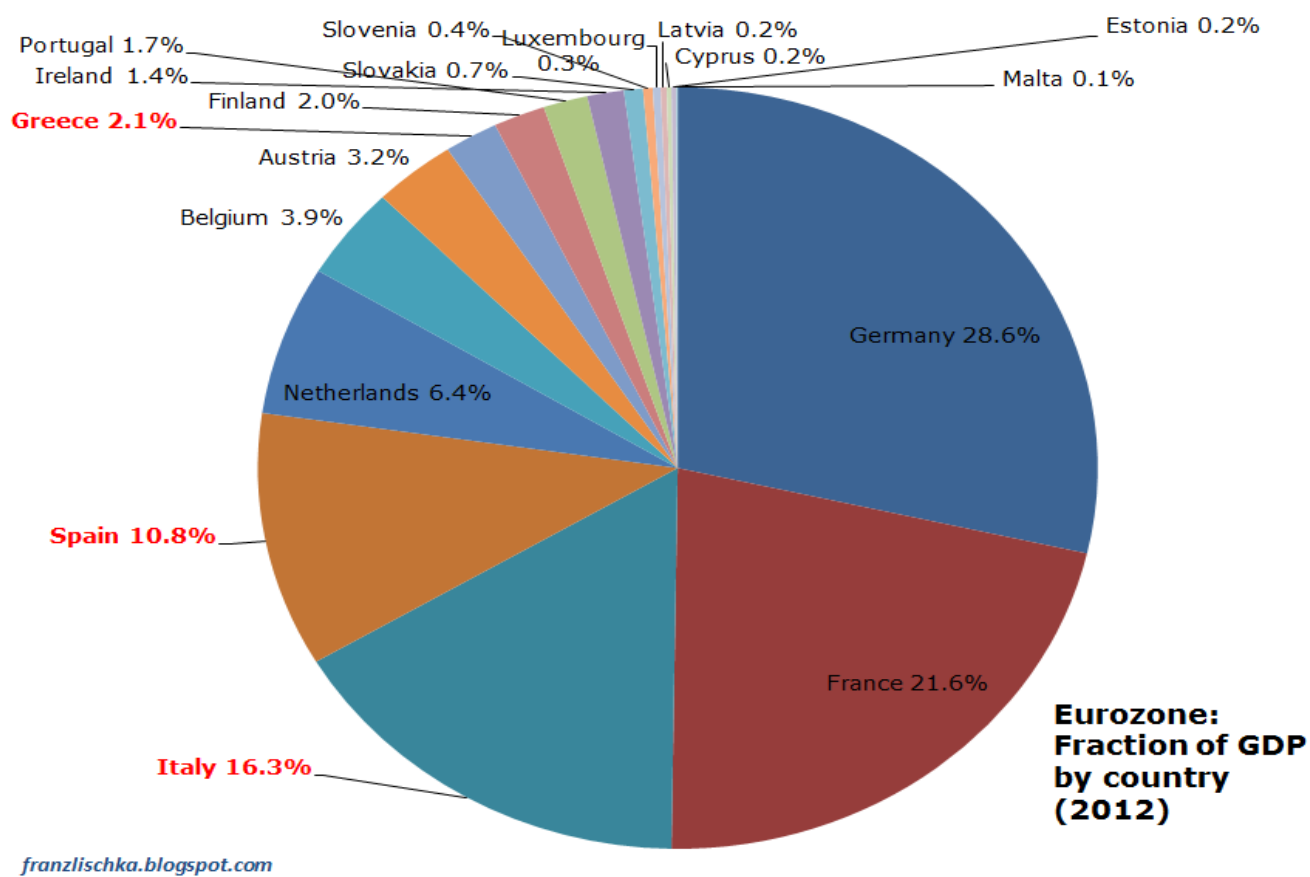

Chart 1: Greece Positioning in the Euro Zone

\section{Literature Review}

In view of the seriousness of the recent crisis in Greece, a number of research studies have been conducted on different issues in which Greece has been pointed out. Higgins, Matthew, Klitgaard and Thomas (2011) have identified that for several years prior to 2010, countries in the euro area like Greece, Ireland and Portugal periphery engaged in heavy borrowing from foreign private investors, allowing domestic spending to outpace incomes. The study explains how these countries faced debt crises reflecting a loss of investor confidence in the sustainability of their finances. The result had been an abrupt halt in private foreign lending to these economies and shows how the periphery countries became dependent on foreign borrowing and considers the challenges they faced reigniting growth while adjusting to greatly reduced access to foreign capital.

It was referred in The Guardian (17 $7^{\text {th }}$ June 2011) that the Banks with the highest exposure to Greek's problems, after the Greek Banks (6 Banks) amount of exposure $€ 45,971$ millions, the hardest hit for the France (4 Banks) amount of exposure €9,362 millions and the 11 German Banks with stakes of $€ 7,902$ millions in the country. There was also some $€ 2.3$ bn invested by British Banks too. Total 54 Banks from 18 countries took exposure of $€ 91,766$ millions in Greece.

Anastasatou (2012) focussed on the taxation system of Greece. Analysis suggested the problem was mainly in the area of personal income taxation. However, all countries face a bigger challenge when it comes to the Tax compliance of the self-employed. In Greece, an unusually high share of the labour force was self-employed. This was partly due to the "I want to be the boss of myself $\mathrm{f}$ " culture in Greece, but low tax enforcement surely also encouraged Greeks to be self-employed. It was also the structure of the Greek economy that potentially allowed for the occurrence of more incidents of tax evasion compared to other countries.

Pagoulatos (2013) The Greek economic crisis was mainly the result of national failures but also that of the Eurozone's systemic defects. Greece faced a Great Depression, having lost over one fourth of its 2008 GDP, with unemployment hovering at $27 \%$ and youth unemployment at $60 \%$ levels. Much of the large output loss resulted from the fiscal consolidation and internal devaluation policies and had been aggravated by the uncertainty surrounding the functioning of the Eurozone. Transparency International said that Greece's ranking on perceived levels of public corruption was still the worst in 
the EU - albeit on a par with Italy - even if it had improved from $94^{\text {th }}$ place at the height of the debt crisis in 2012 to $69^{\text {th }}$ in 2015. As per the World Bank indices of good governance, Greek scores declined and converging with other Balkan states and increasingly diverge from the rest of Europe. (The Guardian $-03^{\text {rd }}$ December 2014).

\section{Research Methodology}

3.1 The objectives of the study include:

3.1.1 Critical Analysis of Greece Economic Structure on the basis of its Public Debt, Debt to GDP, GDP, Public Revenue, Public Expenditure, Budget Deficit, Unemployment Rate, Government Bond Yield to know the actual economic condition of Greece.

3.1.2 In depth examining the debt portfolio of Greece to know the exposure to the Greece by the European Union Members, European Central Bank, IMF, Private Investors and critical analysis of Greece Debt Structure along with repayment deadline.

3.1.3 Greece Government's decisions regarding to find the solutions to counter the financial crisis and how governance is more important than growth in respect to Greece issue.

3.1.4 What would be the repercussions on Greece if it decides/ made to leave the Euro Zone.

\subsection{Data Type and Source}

The relevant data has been collected from secondary sources and secondary in nature comprises of published reports from European Central Bank, European Parliament, Directorate General for Research, Economic Affairs Division, Eurostat from the European Commission, World Bank, International Monetary Fund, American Enterprise Institute for Public Policy Research, various journals and magazines, media reports and information browsed from related website and blogs.

\subsection{Sample Size and Profile}

Germany, Italy and Spain have been taken into limelight because these countries have huge exposure in Greece. World Bank's Governance Index has been taken into consideration to know the Governance Quality of the Greece on the World Bank's Parameters. Based on a long-standing research program of the World Bank, the Worldwide Governance Indicators capture six key dimensions viz. Voice and Accountability, Political Stability and Absence of Violence, Government Effectiveness, Regulatory Quality, Rule of Law and Control of Corruption.

\subsection{Time Frame}

Data has been taken from 2000 to 2015 for the analysis of the Premises.

3.5 Methodological Framework

For data analysis, various tools are employed namely tabling, charting, percentage etc.

\section{Critical Analysis of Greece Economic Structure}

The Greek Government-debt crisis (also known as the Greek Depression) started in late 2009. It was the first of five sovereign debt crises in the euro zone - later referred to collectively as the European debt crisis. In Greece, triggers included the turmoil of the Great Recession, structural weaknesses in the Greek economy and a sudden confidence-crisis among the lenders.

In late 2009, fears developed about Greece's ability to meet its debt obligations, due to revelations that previous data on government debt levels and deficits had been misreported by the Greek Government. This led to building of confidence-crisis, indicated by a widening of bond yield spreads of bond and the cost of risk insurance on credit default swaps compared to the other Euro Zone countries - Germany in particular. In 2012, Greece's Government had the largest sovereign debt default in history. On June 30, 2015, Greece became the first developed country to fail to make an IMF Loan repayment. At that time, Greece's government had debts of $€ 323$ bn. 
Table 1: Important Economic Indicators of Greece

\begin{tabular}{|l|l|l|l|l|l|l|l|l|}
\hline Year & $\begin{array}{l}\text { Public } \\
\text { Reven } \\
\text { ue } \\
\text { of } \\
\text { GDP) }\end{array}$ & $\begin{array}{l}\text { Public } \\
\text { Expenditu } \\
\text { re of } \\
\text { GDP) }\end{array}$ & $\begin{array}{l}\text { Budget } \\
\text { Balance } \\
\mathbf{\%} \text { of } \\
\text { GDP) }\end{array}$ & $\begin{array}{l}\text { Real } \\
\text { GDP } \\
\text { Growth } \\
\mathbf{\%}\end{array}$ & $\begin{array}{l}\text { Public } \\
\text { Debt } \\
\text { (Billio } \\
\text { n } \\
\text { Euro) }\end{array}$ & $\begin{array}{l}\text { Debt } \\
\text { to } \\
\text { GDP } \\
\text { Ratio } \\
\text { \% }\end{array}$ & $\begin{array}{l}\text { Unemplo } \\
\text { yment } \\
\text { Rate \% }\end{array}$ & $\begin{array}{l}\text { Governme } \\
\text { nt } \\
\text { Yield \%ond } \\
\text { (Long } \\
\text { Term) }\end{array}$ \\
\hline 2000 & 43.4 & 47.1 & -3.7 & 4.0 & 141.2 & 99.6 & 11.35 & 6.60 \\
\hline 2001 & 41.3 & 45.8 & -4.5 & 3.7 & 152.1 & 100.1 & 10.90 & 5.35 \\
\hline 2002 & 40.6 & 45.5 & -4.9 & 3.2 & 159.5 & 98.3 & 10.36 & 5.24 \\
\hline 2003 & 39.4 & 45.1 & -5.7 & 6.6 & 168.3 & 94.2 & 9.79 & 4.43 \\
\hline 2004 & 38.4 & 46.0 & -7.6 & 5.0 & 183.5 & 95.1 & 10.59 & 4.37 \\
\hline 2005 & 39.0 & 44.4 & -5.5 & 0.9 & 212.8 & 106.9 & 9.99 & 3.69 \\
\hline 2006 & 38.7 & 44.9 & -6.1 & 5.8 & 225.3 & 103.4 & 9.01 & 3.60 \\
\hline 2007 & 40.2 & 46.9 & -6.7 & 3.5 & 240.0 & 103.1 & 8.40 & 4.28 \\
\hline 2008 & 40.6 & 50.6 & -9.9 & -0.4 & 264.6 & 109.3 & 7.76 & 4.40 \\
\hline 2009 & 38.7 & 54.0 & -15.3 & -4.4 & 301.0 & 126.8 & 9.62 & 5.60 \\
\hline 2010 & 41.1 & 52.2 & -11.1 & -5.4 & 330.3 & 146.0 & 12.72 & 6.02 \\
\hline 2011 & 43.8 & 54.0 & -10.2 & -8.9 & 356.0 & 171.4 & 17.87 & 11.73 \\
\hline 2012 & 45.7 & 54.4 & -8.7 & -6.6 & 304.7 & 156.9 & 24.44 & 25.91 \\
\hline 2013 & 47.8 & 60.1 & -12.3 & -3.9 & 319.2 & 175.0 & 27.47 & 11.10 \\
\hline 2014 & 45.8 & 49.3 & -3.5 & 0.8 & 317.1 & 177.1 & 26.45 & 8.18 \\
\hline 2015 & 37.3 & 50.2 & -2.1 & 0.5 & 320.4 & 180.2 & 25.60 & 9.48 \\
\hline
\end{tabular}

Above Table 1 shows the important economic figures which explain the overall economic performance of the Greece in last 10 years. Economy started to give red signal from 2008, where Budget Balance was $-9.9 \%$ (\% of GDP), Real GDP Growth turned to negative at $-0.4 \%$ in 2008 and Public Debt increased upto 264.60 billion Euros during the same year. Condition became worst when Budget Balance became highly negative at $-15.3(\%$ of GDP), Real GDP declined to $-4.4 \%$ and Debt to GDP Ratio hiked from 109.3(in 2008) to 126.8 in 2009. Highest negative growth rate and Public Debt recorded at $-8.9 \%$ and 356 billion euros respectively, in 2011. Highest Unemployment Rate recorded at $27.47 \%$ in 2013 , whereas the secondary market yields of government bonds, with a remaining close to 10 years, recorded highest at $25.91 \%$ in 2012.

Table 2: Greece's Public Revenue Vs. Public Expenditure

Greece's Public Revenue Vs. Public Expenditure

\begin{tabular}{|c|c|c|}
\hline Year & Public Expenditure (\% of GDP) & Public Revenue (\% of GDP) \\
\hline 2000 & 47.10 & 43.40 \\
\hline 2001 & 45.80 & 41.30 \\
\hline 2002 & 45.50 & 40.60 \\
\hline 2003 & 45.10 & 39.40 \\
\hline 2004 & 46.00 & 38.40 \\
\hline 2005 & 44.40 & 39.00 \\
\hline 2006 & 44.90 & 38.70 \\
\hline 2007 & 46.90 & 40.20 \\
\hline 2008 & 50.60 & 40.60 \\
\hline 2009 & 54.00 & 38.70 \\
\hline 2010 & 52.20 & 41.10 \\
\hline 2011 & 54.40 & 43.80 \\
\hline 2012 & 54.40 & 45.70 \\
\hline 2013 & 60.10 & 47.80 \\
\hline 2014 & 49.30 & 45.80 \\
\hline 2015 & 50.20 & 37.30 \\
\hline
\end{tabular}




\begin{tabular}{|l|c|c|}
\hline *Greece Public Revenue Vs Public Expenditure (\% of GDP) Net \% Change \\
\hline Year & $\begin{array}{l}\text { Net \% change Public Expenditure (\% of } \\
\text { GDP) }\end{array}$ & $\begin{array}{l}\text { Net \% Change Public Revenue } \\
\text { GDP) }\end{array}$ \\
\hline 2001 & $-2.76 \%$ & $-4.84 \%$ \\
\hline 2002 & $-0.66 \%$ & $-1.69 \%$ \\
\hline 2003 & $-0.88 \%$ & $-2.96 \%$ \\
\hline 2004 & $2.00 \%$ & $-2.54 \%$ \\
\hline 2005 & $-3.48 \%$ & $1.56 \%$ \\
\hline 2006 & $1.13 \%$ & $-0.77 \%$ \\
\hline 2007 & $4.45 \%$ & $3.88 \%$ \\
\hline 2008 & $7.89 \%$ & $1.00 \%$ \\
\hline 2009 & $6.72 \%$ & $-4.68 \%$ \\
\hline 2010 & $-3.33 \%$ & $6.20 \%$ \\
\hline 2011 & $4.21 \%$ & $6.57 \%$ \\
\hline 2012 & $0.00 \%$ & $4.34 \%$ \\
\hline 2013 & $10.48 \%$ & $4.60 \%$ \\
\hline 2014 & $-17.97 \%$ & $-4.18 \%$ \\
\hline 2015 & $1.83 \%$ & $-18.56 \%$ \\
\hline
\end{tabular}

Table 2 explains the percentage of Greece Government Revenue and Spending to GDP. After analysing the above table, it is clear that Government was not able to manage its revenue and spending surpassed the revenue in 2004,2006,2008,2009 and 2013.

- Government Revenue decelerated by $-2.54 \%$ in 2004 in comparison to 2003 while the Expenditure accentuated by $2 \%$ during the same period.

- Government Revenue decelerated by $-0.77 \%$ in 2006 in comparison to 2005 while the Expenditure increased by $1.13 \%$ during the same period.

- Government Revenue increased by $1 \%$ in 2008 in comparison to 2007 while the Expenditure also increased by $7.89 \%$ during the same period.

- Government Revenue decelerated by $-4.68 \%$ in 2009 in comparison to 2008 while the Expenditure accentuated by $6.72 \%$ during the same period.

- Government Revenue increased by $4.60 \%$ in 2013 in comparison to 2012 while the Expenditure increased sharply by $10.48 \%$ during the same period.

The Greece Government spending was 9.18\% which is the average of 2004, 2006, 2008 and 2013 while the average Revenue for the same period was $2.80 \%$. As per the European Commission forecast, Greece Government Revenue will decline by $-18.56 \%$ in 2015 in comparison to 2014 and the Expenditure would increase by $1.83 \%$ in 2015 during the same period.

Note: * Greece's Public Revenue Vs Public Expenditure (\% of GDP) Net Change is calculated as follows : Net \% change in Public Expenditure $(\%$ of GDP $)=\{[$ Current Public Expenditure(\% of GDP) - Previous Public Expenditure(\% of GDP)] / Previous Public Expenditure (\% of GDP)*100 and 2) Net $\%$ Change in Public Revenue $(\%$ of GDP $)=\{[$ Current Public Revenue $(\%$ of GDP $)]-$ Previous Public Revenue (\% of GDP)] / Previous Public Revenue (\% of GDP) $\} * 100$ 


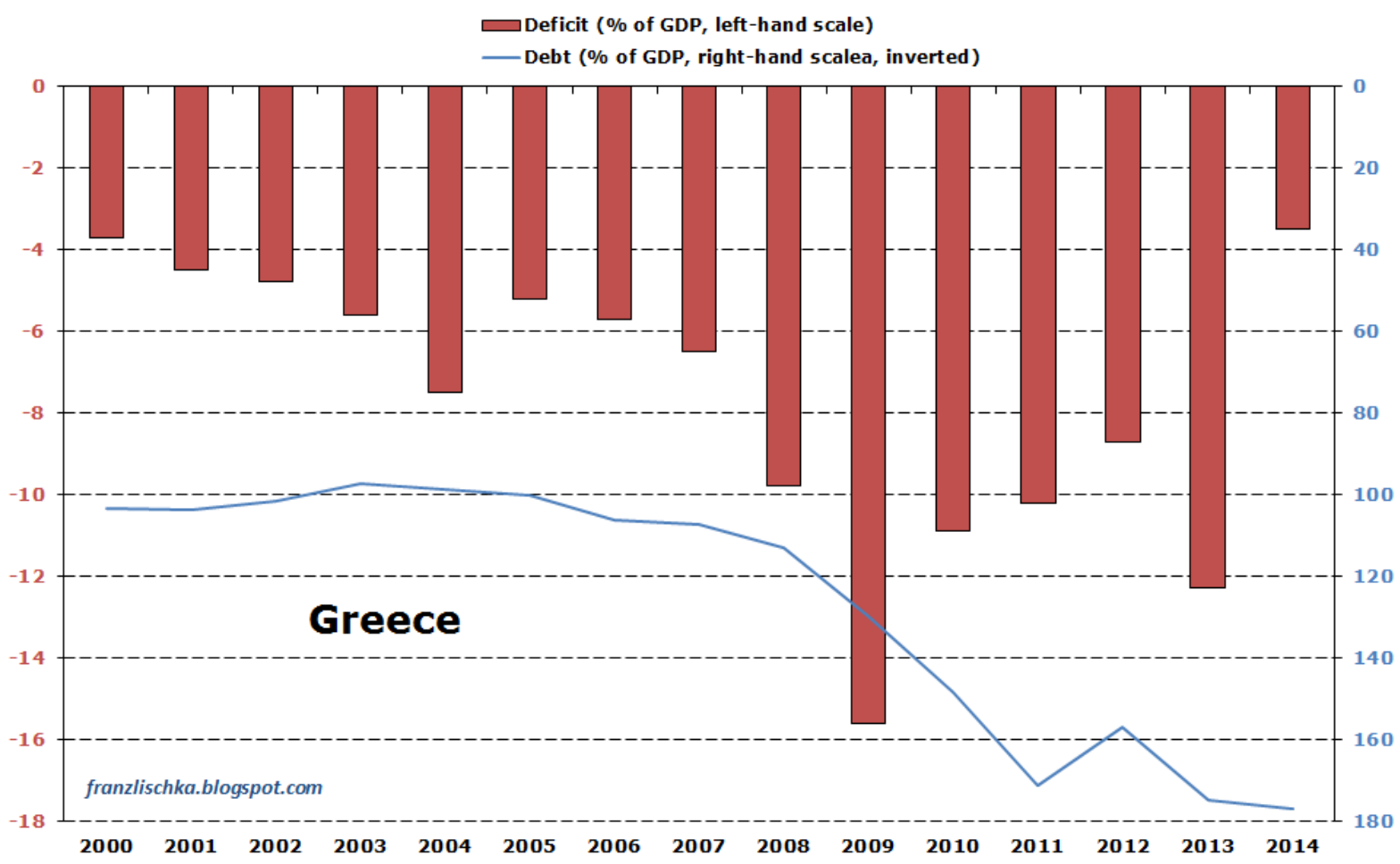

Chart 2: Greece Budget Balance (Calculated as Public Revenue - Public Expenditure)

\subsection{Inferences}

After analysing the Table 1 and Chart 1, it is clear that Greece Public Expenditure was more than its Public Revenue. As Budget Balance (\% of GDP) shows that it was at -3 in 2000 and recorded a steep fall to -15.3 in 2009 which gives clear signal that there was a perceptible disequilibrium between the revenue and expenditure in the Greece economy and the Government was not able to manage the same. As per the European Commission forecast, Greece Budget Balance would be at -2.1 in 2015.

\subsection{Reasons for exorbitant hike in Public Expenditure by the Government:}

Greece's public sector, comparing with the size of its economy, is clearly large, and at the upper end of European benchmarks. At the same time, Greek public sector is subjected to multiplicity of controls and overlapping of responsibilities authorities and ministries resulting thereby stiff hindrances in smooth operations of the business. An example of this is that a total of 13 Ministries are involved in 27 tourism related activities and responsibilities.

According to the Stockholm International Peace Research Institute, the Greece's annual military budget amounted to $\$ 4$ billion, which accounted to 2.2 per cent of the nation's GDP -a colossal drain on the economy. To put Greece's military spend into perspective, it is double the ratio that most other EU countries currently spend on defence. For example, Germany spends 1.2 per cent of GDP, Italy 1.1 per cent, Netherlands 1.2 per cent and Belgium 1.1 per cent.

During the decade up to the onset of crisis in 2010, Greece was regularly spending 7 per cent of its GDP on military. Some estimate that during that decade the country spent a Total of $\$ 150$ billion on defence - or half of the current debt pile. If Greece were to cut its outsized military budget by half that would generate $\$ 2$ billion in one year alone, which would pay off its immediate bill to the IMF and help the country reach a 1 per cent budget surplus that the Troika has set for 2015. In other words, that source of finance would obviate any further need for cutting pensions and workers' salaries.

\subsection{Reason for the less Public Revenue by the Government}

As in many Mediterranean countries, where family-owned businesses are still predominant, the backbone of the Greek economy comprises mostly small and micro enterprises. For example, around $30 \%$ of the manufacturing employment in the country is in firms with nine or fewer employees. In contrast, Italy has just $15 \%$ of employees in this segment and Germany has only 5\%. In addition to 
family ownership, a number of scale disincentives have resulted in the lack of large business. These includes several overregulated areas of economic activity, a frustrating bureaucracy that must approve investments, tax laws and administration practices that hinder scale and labour restriction on large enterprises. On the parameter of "Overall Product Market Regulation Index" which is measured by the Organization for Economic Cooperation and Development (OECD), which measures the overall market regulation environment every after 5 years. Greece is having highest score. "Higher score indicates more regulated business environment". Overall Product Market Regulation Index includes the following things - State Control, Public Ownership Government Involvement in Network sectors, Direct Control on Business Enterprises, Command and Control Regulation, Barriers to Entrepreneurship, Complexity of Regulatory Procedures, License and Permit System, Barriers in Service Sectors, Administrative burden on start-ups.

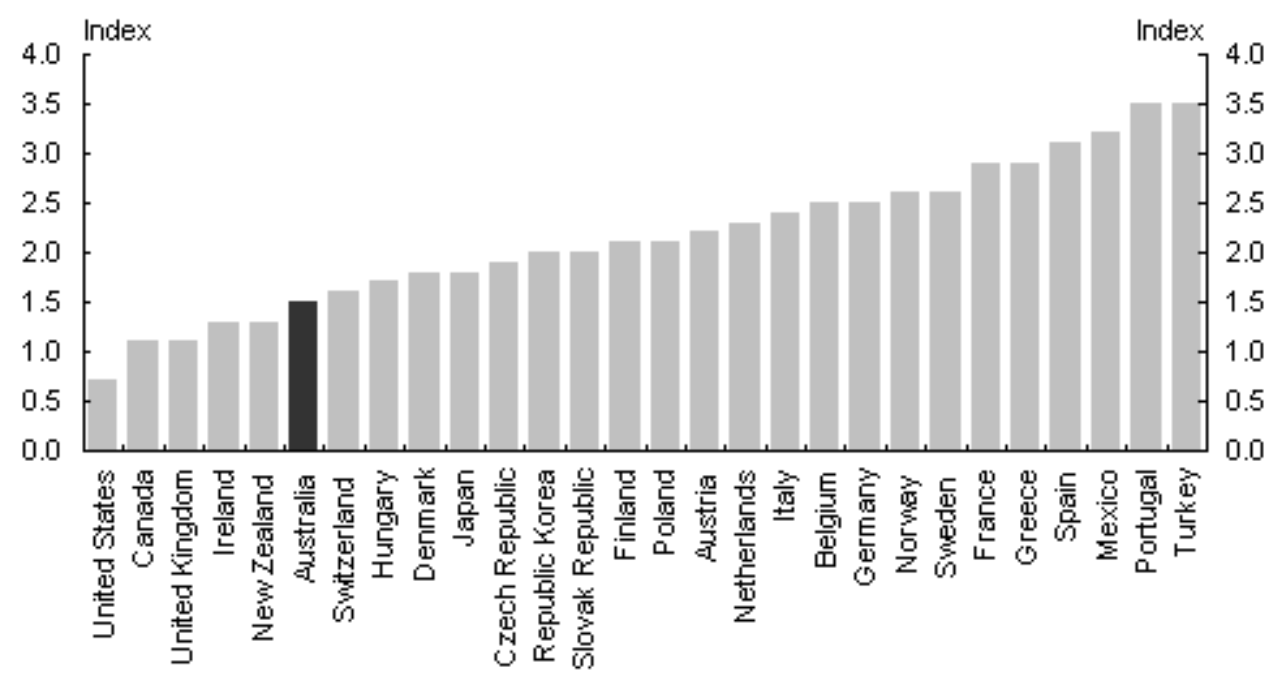

Chart 3: Overall Product Market Regulation Index 2003
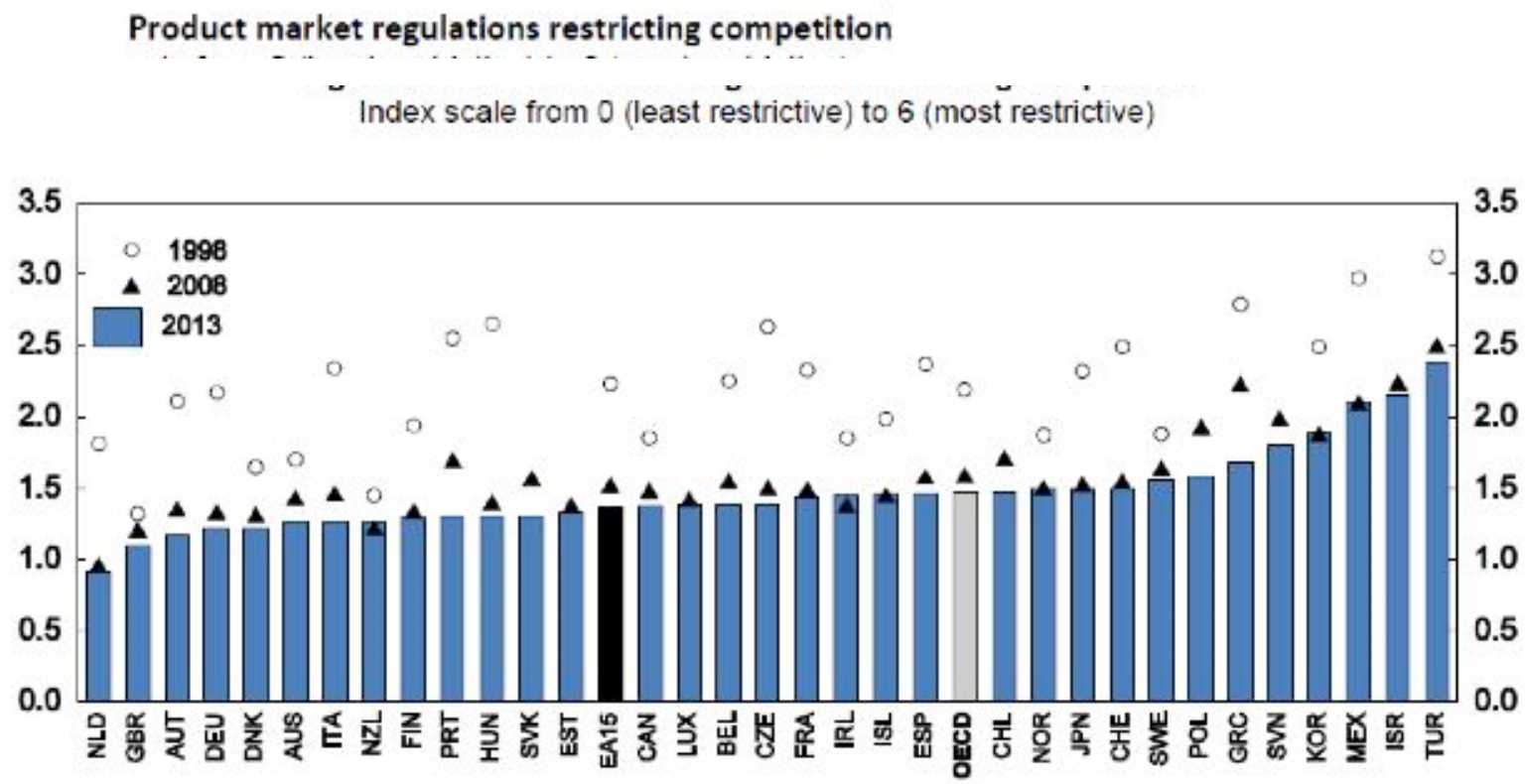

Chart 4: Overall Product Market Regulation Index of 1998, 2008 and 2013

\section{Critical Examining of Greece Debt Portfolio}

Currently, Greece has 301.52 Billion Euros debt as on first quarter of 2015. Greece Debt was noticed from 2004 where, it increased by $9.03 \%$ to 183.50 Billion Euros (2004) from 168.30 Billion Euros 
(2003). Greece Debt started its upward journey with an average of $63.82 \%$ from 2005 to 2011 . In absolute terms, the Greece debt became double within 9 years to 365 Billion Euros (2011) from 168.30 Billion Euros (2003). Finally, Greece Debt gave alarm signal from 2008 in the Euro zone and became deep in 2009.

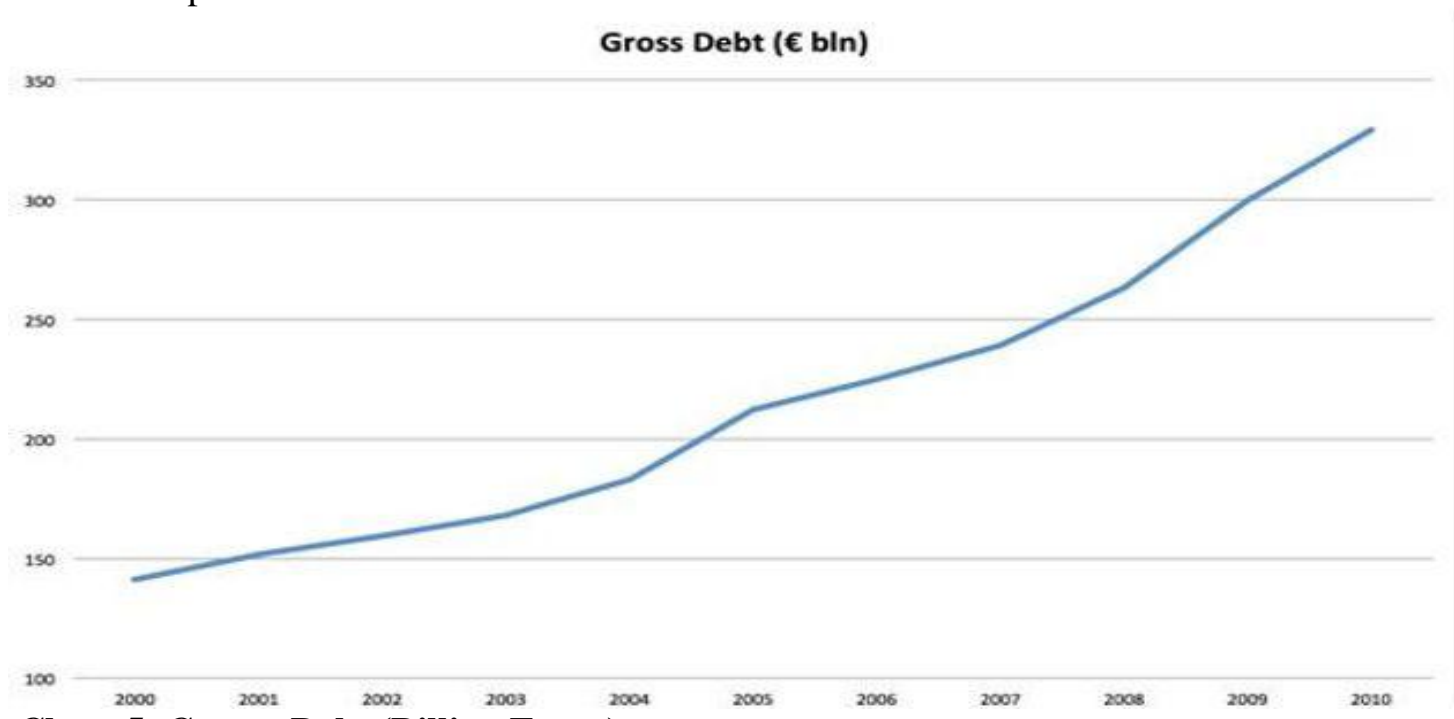

Chart 5: Greece Debt (Billion Euros)

\subsection{Greece Creditors}

European countries lent to Greece through two newly created Institutions - 53 Billion Euros through the Bilateral Loan Facility and 142 Billion Euros through European Financial Stability Facility. These are in addition to each country's contribution to the IMF. Total Loan Amount as end of 2014 was 320 Billion Euros. Germany holds 57 Billion Euros, France holds 43 Billion Euros, Italy holds 38 Billion Euros, Spain holds 25 Billion Euros and these are the euro zone countries that are holding major exposure in Greece.

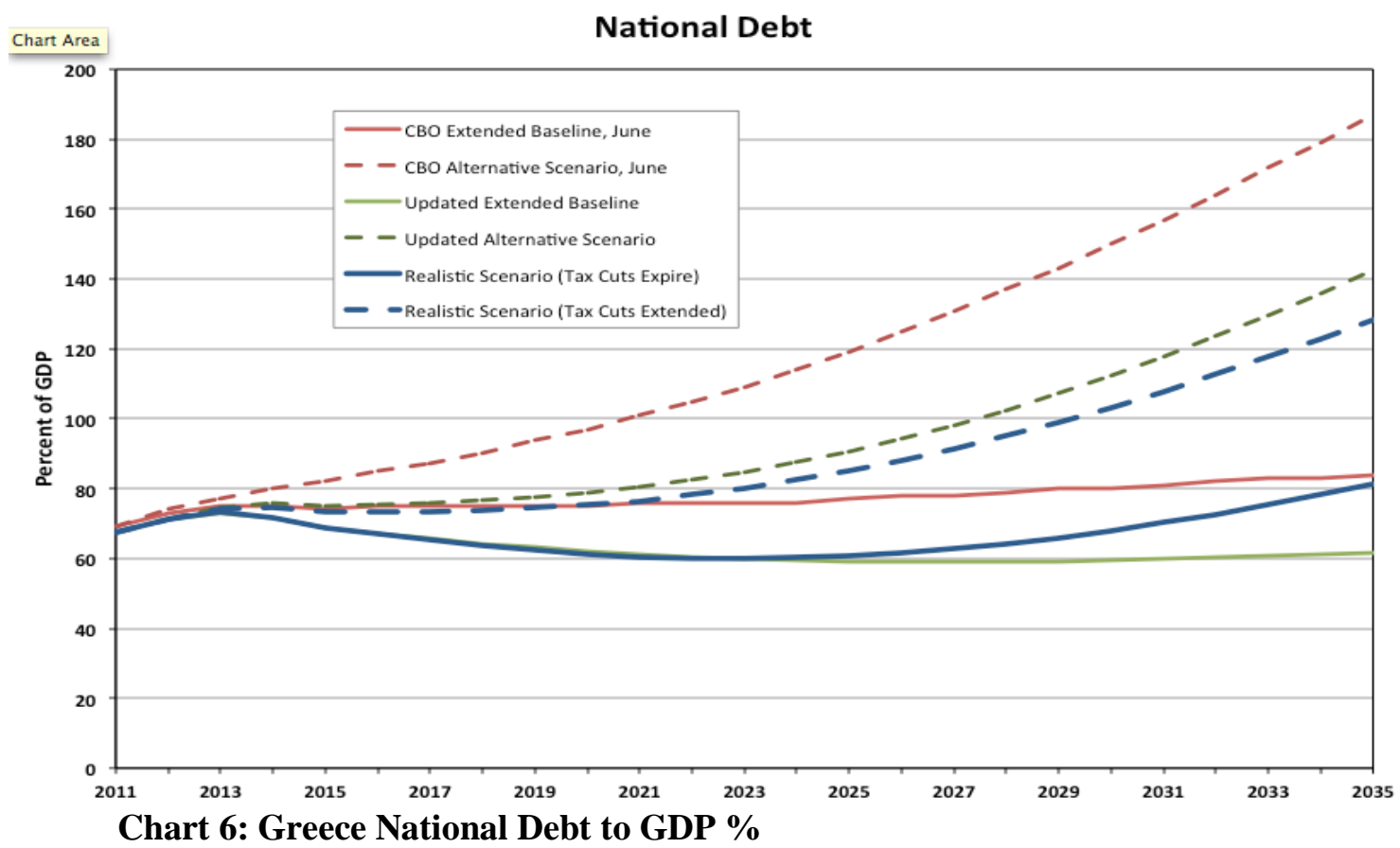

There are major seven creditors who have provided loans to Greece

1. Treasury Bill Holders

2. European Central Bank 
3. Eurozone Governments

4. European Investment Bank

5. European Financial Stability Facility

6. Private Investors

7. International Monetary Fund

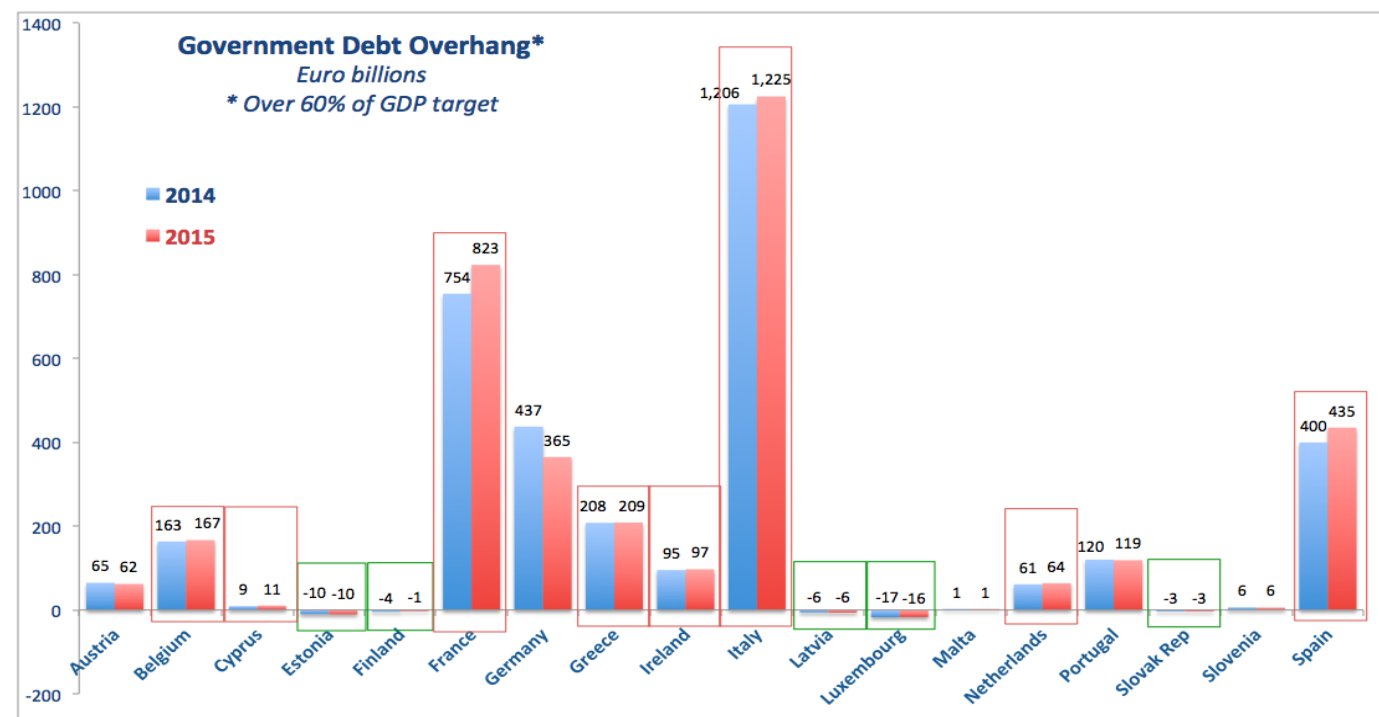

Chart 7: Greece Government Debt to various Countries (in Euro Billions)

\section{Greece Re-payment Deadline to its Creditors}

Greece has to pay 18.2 Billion Euros to its three creditors in 2015 and payments will be to Treasury Bill Holders, International Monetary Fund and European Central Bank. The entire loan of the Greece will be paid by April 2054 .

1. Treasury Bill Holders - 11.8 Billion Euros in 2015

\begin{tabular}{|l|l|}
\hline Deadline Dates & Amount in Billion Euros \\
\hline 14 th August 2015 & 1.4 \\
\hline 04 th September 2015 & 1.4 \\
\hline $11^{\text {th }}$ September 2015 & 1.6 \\
\hline $18^{\text {th }}$ September 2015 & 1.6 \\
\hline $09^{\text {th }}$ October 2015 & 1.4 \\
\hline $16^{\text {th }}$ October 2015 & 1 \\
\hline $06^{\text {th }}$ November 2015 & 1.4 \\
\hline $11^{\text {th }}$ December 2015 & 2 \\
\hline Total in 2015 & $11.8 \quad$ Billion Euros \\
\hline
\end{tabular}

2. International Monetary Fund - 3.2 Billion Euros in 2015

\begin{tabular}{|l|l|}
\hline Deadline Dates & Amount in Billion Euros \\
\hline 04 th September 2015 & 0.3 \\
\hline 14 th September 2015 & 0.3 \\
\hline $16^{\text {th }}$ September 2015 & 0.6 \\
\hline $21^{\text {th }}$ September 2015 & 0.3 \\
\hline $13^{\text {th }}$ October 2015 & 0.5 \\
\hline $07^{\text {th }}$ December 2015 & 0.3 \\
\hline $16^{\text {th }}$ December 2015 & 0.6 \\
\hline $21^{\text {th }}$ December 2015 & 0.3 \\
\hline Total in 2015 & 3.2 Billion Euros \\
\hline
\end{tabular}


3. European Central Bank - 3.2 Billion Euros in 2015

\begin{tabular}{|l|l|}
\hline Deadline Dates & Amount in Billion Euros \\
\hline 20th August 2015 & 3.2 \\
\hline
\end{tabular}

Final Deadline or Last Payment Due of all major 7 creditors of Greece

\begin{tabular}{|l|l|l|}
\hline Sr.No. & Greece Creditors & Last Payment Due \\
\hline 1 & Treasury Bill Holders & $05^{\text {th }}$ December 2016 \\
\hline 2 & $\begin{array}{l}\text { International Monetary } \\
\text { Fund }\end{array}$ & $3^{\text {rd }}$ June 2024 \\
\hline 3 & European Central Bank & $20^{\text {th }}$ March 2026 \\
\hline 4 & Eurozone Governments & $15^{\text {th }}$ September 2041 \\
\hline 5 & $\begin{array}{l}\text { European Financial } \\
\text { Stability Facility }\end{array}$ & $28^{\text {th }}$ April 2054 \\
\hline 6 & Private Investors & $24^{\text {th }}$ February 2042 \\
\hline 7 & $\begin{array}{l}\text { European Investment } \\
\text { Bank }\end{array}$ & $25^{\text {th }}$ July 2030 \\
\hline
\end{tabular}

\section{Greece Government Performance on World Bank's Parameters}

Based on a long-standing research program of the World Bank, the World wide Governance Indicators capture six key dimensions of Governance: High Value shows High Quality and Low value shows Less Quality.

7.1 Voice and Accountability: Reflects Perceptions of the extent to which a country's citizens are able to participate in selecting their government, as well as freedom of expression, freedom of association and a free media.

7.2 Political Stability and Lack of Violence: Reflects perceptions of the likelihood that the government will be destabilized or overthrown by unconstitutional or violent means, including politically motivated violence and terrorism.

7.3 Government Effectiveness: Reflects perceptions of the quality of public services, the quality of the civil service and the degree of its independence from political pressures, the quality of policy formulation and implementation and the credibility of the government's commitment to such policies.

7.4 Regulatory Quality: Reflects perceptions of the ability of the government to formulate and implement sound policies and regulations that permit and promote private sector development.

7.5 Rule of Law: Reflects perceptions of the extent to which agents have confidence in and abide by the rules of society, and in particular the quality of contract enforcement, property rights, the police and the courts, as well as the likelihood of crime and violence.

7.6 Control of Corruption: Reflects perceptions of the extent to which public power is exercised for private gain, including both petty and grand forms of corruption, as well as "capture" of the state by elites and private interests.

\section{Repercussions on Greece if it decides/made to leave the Euro Zone}

Leaving the Euro Zone would be an incalculable economic risk for Greece. There would be multiple impacts not only on the Greece but also on the world economy too.

\subsection{What would happen to Greece?}

- Living Standards could fall by $80 \%$ within a few weeks of exit.

- Unable to borrow from anyone (not even other European Governments), the Greek Government would simply run out of Euros.

- It would have to pay social benefits and civil servants wages in IOUs (if it pays them at all) until a few non-euro currency can be introduced.

- The Government would not be able to repay its debts, amounting to a total debt of 301.52 Billion Euros as on First Quarter of 2015. 
- The Government would have to impose an embargo on withdrawals and siphoning off money out of the country. This could lead to chaos to ordinary Greeks who would try to empty their Bank accounts before they get converted into a new currency. Then the currency that replaces the Euros might be extremely weak, have high inflation, and that would mean that prices for oil, food would be very expensive.

- Greek businesses would face a legal and financial disaster. Some contracts governed by Greek law would be converted into a new currency, while other foreign law contracts would remain in Euros. Many contracts could end up in legal disputes over whether they should be converted or not.

- Greek companies who still owe big debts in Euros to foreign lenders but whose main sources of income are converted to a devalued non-euro currency, would be unable to repay their debts.

\subsection{What would happen to the wider Euro Zone?}

- Nervous depositors in other struggling euro zone countries such as Germany, Spain or Italy may also move their money to the safety of a German bank account sparking a banking crisis in Southern Europe.

- Confidence in other Banks that have lent heavily to southern Europe - such as the French banks, German Banks and British banks - could also be affected. Total 54 Banks from 18 countries have taken exposure in Greece. The banking crisis could conceivably spread worldwide, just as it happened in 2008.

- In the wider Euro Zone, businesses afraid of the euro's future, may cut investments. Faced with a barrage of bad news in the press, ordinary people cut back their own spending. All of this could push the euro zone into recession.

- The euro could lose its value in the currency markets, providing some relief for the euro zone by making its exports more competitive in international trade. But the flipside is that imports from the rest of the world would become more expensive especially the US, UK and Japan.

\subsection{What impact it would have on India?}

- Interaction between India and Greece goes back to antiquity. In modern times, the two countries have developed a warm relationship based on a common commitment to democracy, peace and development in the world and to a social system imbued with principles of justice and equality. India and Greece also share common approaches to many International issues, such as UN reforms and Cyprus. Greece has been consistently supportive of India's core foreign policy objectives. Presently bilateral commercial and economic relations do not measure upto the closeness the two countries have politically, exacerbated by the fact that Greece is also going through an economic and financial crisis. FDI is negligible both ways.

- The bilateral trades of both the countries would be adversely affected. The main items of Greece's exports to India are Machinery, rubber and plastic products, cotton, copper products, iron and steel products and chemicals. The main items of India's exports are machinery, automobiles and auto parts, iron and steel, aluminium, copper, dyes and chemicals, textiles and garments.

- There are no major investments in Greece or in India from either side, but some companies in the field of IT and construction are making the way.

- There are currently five Greek companies operating in India - The Pisani Group, M.J.Mallis \& Co., European Dynamics, Frigoglass and Topos.

\subsection{Exposure of Indian Companies in Greece}

- Infosys, TCS, I-Flex, Jain Irrigation Systems, Quoprro Global Services, Tata Steel, Indian Register of Shipping. 


\section{Conclusion}

After examining and critical analysis of all the facts, it is concluded that Government of Greece did not perform on Good Governance parameters viz. Voice and Accountability, Political Stability and Lack of Violence, Government Effectiveness, Regulatory Quality, Rule of Law and Control of Corruption and took wrong decision on policy making side for past 13 years, resulting Greece has 301.52 Billion Euros debt as on first quarter of 2015 and facing high debt Debt to GDP Ratio \% @ 180 for the same. The last instalment of its due is becoming in April 2054. Because of 13 years of bad governance, Greece is in huge debt and it will take 39 years from the present to repay its all debts.

If Greece decides to leave the Euro Zone then Germany would be the first country to face the unwelcomed impact from the event because it has more than 50 Billion Euros exposure in the country and Germany contribution to the European economy in terms of GDP is $28 \%$. If Germany suffers then whole euro zone would be in deep recession. As per the Indian Market is concern, India has no major exposure in Greece economy directly except to some Indian Companies but India has trade relations with Germany, France, Italy and other European countries and there are more than 25 FIIs from Germany, 35 FIIs from France in Indian Stock Market. In case of Greece exit Indian markets would suffer indirectly in terms of trade relations but directly in terms of Indian Stock market.

\section{References}

[1] Matthew Higgins and Thomas Klitgaard, "Saving Imbalances and the Euro Area Sovereign Debt Crisis", Current Issues in Economics and Finance (Federal Reserve Bank of New York), Vol.17 No.3, November 2010.

[2]"Greece Debt Crisis: How exposed is your Bank?" The Guardian, 17 June 2011. http://www.theguardian.com/news/datablog/2011/jun/17/greece-debt-crisis-bank-exposed

[3] George Pagoulatos, Professor of European Politics \& Economy, Athens University of Economics \& Business, "The Greek Economy is not adjusting", Hellenic Foundation for European \& Foreign Policy - Greek Myths and Reality, P.P. 6-13. http://www.brookings.edu/ /media/research/files/papers/2013/08/06-greece-recoverydervis/eliamep_brookings-greek-myths-and-reality.pdf

[4] "Corruption still alive and well in post-bailout Greece. "The Guardian, 3 December 2014. http://www.theguardian.com/world/2014/dec/03/greece-corruption-alive-and-well [5] Desmond Lachman, American Enterprise Institute for Public Policy Research, "Economic Crisis: The Global Impact of Greek Default", Testimony for the Senate Banking Subcommittee on National Security and International Trade and Finance, $25^{\text {th }}$ June 2015.

[6] Maxime Sbaihi, Bloomberg Economist, "Who Hurts Most If Greece defaults?" Bloomberg BriefEconomics Europe, $07^{\text {th }}$ January 2015.

[7] "Greek debt crisis: Who has most to lose?" CNN Money (London), 02 ${ }^{\text {nd }}$ February 2015. http://money.cnn.com/2015/01/28/investing/greek-debt-who-has-most-to-lose/index.html

[8] "Greek military spending the real cause for its economy collapse, not public spending." Sott.net, $29^{\text {th }}$ June 2015. http://www.sott.net/article/298524-Greek-military-spending-the-real-cause-for-itseconomic-collapse-not-public-spending

[9] "First quarter of 2015 compared with Fourth quarter of 2014" Eurostate New Releases Euroindicators, $22^{\text {nd }}$ July 2015, P.P. 4. http://ec.europa.eu/eurostat/documents/2995521/6923259/222072015-AP-EN.pdf/bf173a0e-0eba-4ab9-878c-6db8d1f6452b

[10] "Greece 'most corrupt' EU country, new survey reveals". BBC, 5 December 2012. http://www.bbc.com/news/business-20605869

[11] "Greece records lowest life satisfaction rating of all OECD countries", The Guardian, $01^{\text {st }}$ July 2015.

http://www.theguardian.com/news/datablog/2015/jul/01/greece-life-satisfaction-rating-oecd-countries 